\title{
Traffic Information Zone and its implementation in the Czech Republic
}

\author{
Tomáš Volena \\ ATM Systems Laboratory, \\ Department of Air Transport, Faculty of Transportation \\ Sciences, Czech Technical University \\ Horská 3, Praha 2, 128 03, Czech Republic \\ e-mail: volentom@fd.cvut.cz
}

\author{
Jakub Kraus \\ ATM Systems Laboratory, \\ Department of Air Transport, Faculty of Transportation \\ Sciences, Czech Technical University \\ Horská 3, Praha 2, 128 03, Czech Republic \\ e-mail: kraus@fd.cvut.cz
}

\begin{abstract}
This article deals with the possibility of introduction of a new type of airspace in the Czech Republic - Traffic Information Zone. It states status quo of uncontrolled aerodromes in the Czech Republic, defines Traffic Information Zone and subsequently copes with the implementation suitability of this airspace in the Czech Republic from the point of view of suitable aerodromes, necessary legislative changes and also appropriate approaches.
\end{abstract}

Keywords- TIZ, Traffic Information Zone, Uncontrolled Aerodromes, AFIS, GNSS, IFR traffic

\section{INTRODUCTION}

Air Traffic Control is a discipline which needs constant development in order to ensure its safety, reliability and effectiveness qualities. During the global financial crisis in 2009 we witnessed temporary recession in air travel and it off course influenced the following years. Contemporary estimations predict that the commercial air transport will grow about $3 \%$ per year. It is needed to make sure that this particular growth will be achieved or rather exceeded. Furthermore, it is expected that airliners and air operators will continue in a bid to lower all the possible costs, including the landing fees and the approach fees. Particularly these two categories of costs can be radically lowered by the use of regional aerodromes which are expected to be evolving very rapidly in the near future. However, necessary measures need to be taken so it is guaranteed that the standards of safety on these aerodromes are sufficient to the global requirements. This issue is granted by few concepts that are used in some countries all over Europe. To support both growth of the air transport and decrease of the airlines costs, which are off course bonded, it is vital to implement some of these concepts in as many countries as possible. All of the concepts can be linked together by common goal which is to introduce the IFR traffic to AFIS aerodromes. AFIS aerodrome, as it is defined in L11 regulation, Appendix $\mathrm{N}$ [3], is an uncontrolled aerodrome on which the Aerodrome Flight Information Service and Alerting Services are provided. However, some experts oppose that the level of safety would not be maintained, because separation is not ensured and not all of the aerodromes meet conditions for the IFR operations. On the other hand it is necessary to emphasize that these objections are naturally handled in the presented concepts.

\section{TRAFFIC INFORMATION ZONE}

\section{A. The Norwegian origin}

One of the possible concepts, which is ascertained to be the most beneficial by many specialists, is named Traffic Information Zone. Firstly, it has been implemented in the Nordic countries and so far it has been proved very effective. However, the reason of the implementation was partially different. The Kingdom of Norway used to have a large number of controlled aerodromes with ATC services. The head of AFIS department in Norway Gunnar Olsen Skårn reports that this situation, however, had been changing throughout the last years. Most of the aerodromes with fewer than 15000 movements per year have been transformed into the AFIS aerodromes in order to cut the costs of the ATC services and necessary maintenance of the aerodromes. As uncontrolled aerodromes, the necessary requirements on the aerodromes and ATC are lowered, consequently the costs are reduced.

\section{B. Rules of TIZ}

Nowadays uncontrolled aerodromes in the Czech Republic are surrounded by an airspace, which is classified as ATZ Aerodrome Traffic Zone. The ATZ is defined with dimensions of a 3NM radius and height $4000 \mathrm{ft}$ AMSL, unless the Civil Aviation Authority states otherwise. The present state is not sufficient for the IFR traffic and accordingly regulations used need to be revised. The solution could be the introduction of the TIZ in the Czech Republic.

Traffic Information Zone is defined as an uncontrolled airspace of defined dimensions extending upwards from the surface of the earth to a specified upper limit within which twoway communications is required for all aircraft and flight information is provided by an AFIS unit. Since Standardized European Rules of the Air introduction in late 2014, TIZ has to be designed within the class $G$ airspace, because the SERA allows usage of the class $\mathrm{F}$ as an interim solution only. This airspace can be described as an uncontrolled equivalent of the CTR in which the IFR traffic is allowed and that is also under the meteorological conditions that do not meet the VMC 
minima. One of the benefits is a possibility to form the airspace as needed and it is not restricted or limited by the CAA. Hence the TIZ is uncontrolled airspace, only pilots are responsible for maintaining separation, even though they receive traffic information from the AFIS officer.

One of the most important characteristics that can be applied to ensure safety is to limit the number of aircrafts in the TIZ. The limitation is mainly determined by the equipment of the AFIS unit, e.g. output from surveillance systems. Furthermore, to ensure the defined separations between aircrafts, specific rules between the AFIS and the superior ATC need to be set. For example when an aircraft is about to enter the TIZ airspace, the ATC officer is obliged to coordinate this act with the AFIS officer at least 15 minutes before ETA to make sure there is no possible conflict situation with other aircraft. Analogously the AFIS officer is obliged to advise the ATC officer of ETD and the runway in use. In case of the TIZ is underneath a TMA, aircraft needs to be given under the control of an ATC in less than 2 minutes after take-off.

Figure 1. Airspace Classification within Norwegian FIR [4]

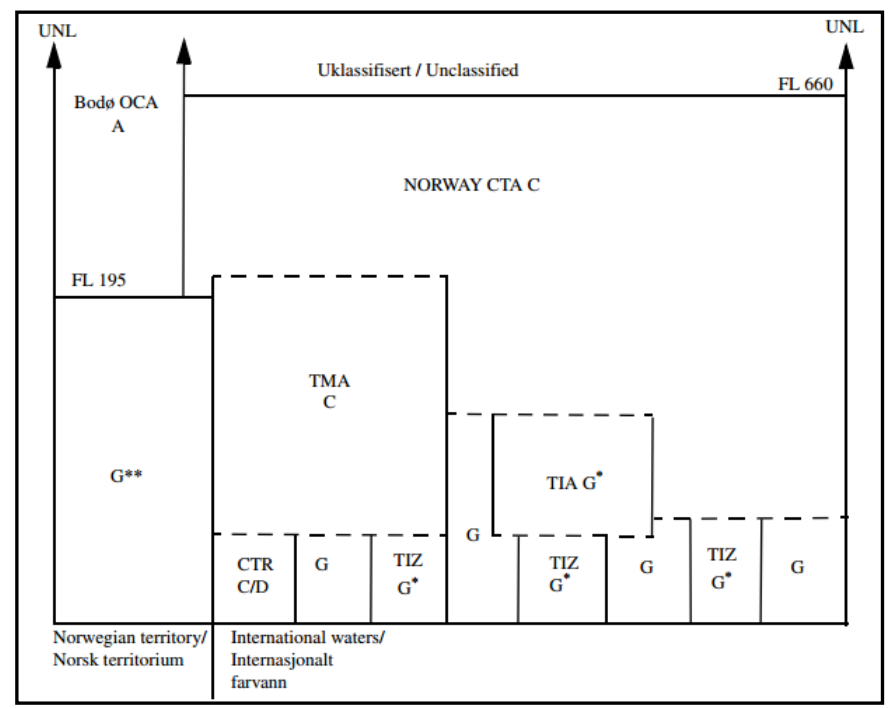

\section{IMPLEMENTATION IN THE CZECH REPUBLIC}

TIZ airspace comes with some indisputable advantages. However, in order to implement completely new airspace with different regulations, further analysis needs to be comprehensively processed. All possible threats must be responsibly evaluated and new regulations must be set. Although costs for the TIZ implementation are not exorbitant, there are some. From this reason, it is vital to analyse which uncontrolled aerodromes are suitable for the implementation. On the selected candidate aerodromes an analysis of series of factors needs to be done. Factors will be divided into categories, such as an examination of the aerodrome's potential, where the analysis of movements, the analysis of the area economic potential and possible future growth will be conducted. Moreover, a next criterion which has to be evaluated is the vicinity around selected aerodromes. This study involves possibly dangerous terrain or problematic areas, such as Temporary Restricted Areas, Temporary Segregated
Areas or Danger Areas. Furthermore, an exploration of the aerodrome's equipment has to be done, that is to analyse approach lightning systems, signs, markings and runway surface.

Firstly, criteria for the candidate aerodromes need to be set. As an initial condition, there will be determined that an aerodrome needs to possess a paved runway. This condition is defined in order to ensure safety and a possible further development of the aerodrome. From total of 84 uncontrolled aerodromes in the Czech Republic, only 15 have a paved runway. These aerodromes are evenly distributed all over the country which is perfect from the reachability point of view.

Another criterion should be the length of a runway. This figure cannot be left out because there can be an aerodrome with length of the runway, on which majority of planned aircrafts could not operate. Consequently, spent costs would come to nothing. On the basis of data by the Civil Aviation Authority, list of the most used aircrafts in the Czech Republic can be made. Furthermore, a number has to be stated to demarcate the quantity of aircrafts above which it makes sense to consider this specific airplane. In accordance with the Aircraft Register, this number is set to 20 pieces. Aircraft Register shows that the most common aircrafts of general aviation which can be modified for the IFR operations are Cessna 172, Cessna 152, L 200 Morava and Piper PA28. These aircrafts have different demands on the runway length, however, Piper PA28 requires the longest runway, and specifically it is 445 meters, based on the Piper PA28 Aircraft Manual. This value will be stated as a minimum runway length for the candidate aerodromes. From all the 15 pre-selected aerodromes, only the Olomouc airport has runway with the length of 420 meters and therefore has to be eliminated from the pre-selection.

TABLE I.

LIST OF THE PRE-SELECTED AERODROMES

\begin{tabular}{||c|c|c||}
\hline AERODROME & ICAO CODE & LENGTH OF RWY \\
\hline České Budějovice & LKCS & $2500 \mathrm{~m}$ \\
\hline Hořovice & LKHV & $1170 \mathrm{~m}$ \\
\hline Hosín & LKHS & $800 \mathrm{~m}$ \\
\hline Hradec Králové & LKHK & $2400 \mathrm{~m}$ \\
\hline Jindřichův Hradec & LKJH & $700 \mathrm{~m}$ \\
\hline Křǐženec & LKKC & $595 \mathrm{~m}$ \\
\hline Mnichovo Hradiště & LKMH & $1550 \mathrm{~m}$ \\
\hline Moravská Třebová & LKMK & $714 \mathrm{~m}$ \\
\hline Olomouc & LKOL & $420 \mathrm{~m}$ \\
\hline Otrokovice & LKOT & $650 \mathrm{~m}$ \\
\hline Panenský Týnec & LKPC & $2505 \mathrm{~m}$ \\
\hline Plzeň - Líně & LKLN & $1450 \mathrm{~m}$ \\
\hline Přerov & LKPO & $2500 \mathrm{~m}$ \\
\hline Příbram & LKPM & $1450 \mathrm{~m}$ \\
\hline Vysoké Mýto & LKVM & $600 \mathrm{~m}$ \\
\hline \hline
\end{tabular}

All 14 candidate aerodromes have been comprehensively analysed and the conclusion is altogether explicit. From the reason of substantial extensiveness of the analysis, only the four finally selected aerodromes are examined in this article. 


\section{A. České Budějovice}

One of the most suitable aerodrome for the TIZ implementation is the Airport České Budějovice. It possesses $2500 \mathrm{~m}$ long concrete runway with a charted clearway, 4 taxiways which are perpendicular to the runway and two APRONs. The runway contains runway designation marking, centre line, threshold marking, aiming point marking and also touchdown zone marking. Moreover, the aerodrome is equipped with the PAPI $3^{\circ}$ lights on the RWY 27. Furthermore, it is necessary to remind the fact that also the technical handling equipment of this airport is more than satisfactory. The company owns 3 airport stairs, a GPU unit, two towbarless aircraft handling tractors and SAAB SARSYS Friction Tester Wagon. Such equipment goes hand in hand with the expected development of the aerodrome in the near future. The capacity of the aerodrome and consequently the air traffic services and the ground services is declared to 16 IFR movements per hour for the RWY 27. However, the capacity of the APRON is limited to two category $\mathrm{C}$ aircrafts. Importantly, in late 2013, budget for the year 2014 has been approved which should provide this airport amount of 95 mil. CZK that is determined for purchasing radionavigation equipment and aerodrome lights. According to Ms. Vodičková, director of external relations of the Airport České Budějovice, this sum of money is for preparatory works only and it is planned to bankroll this project also in 2015, which should include further runway modifications, including runway centre line lights. In reference to the study of applicability of the Airport České Budějovice, it is planned to develop the aerodrome rapidly in the future as mentioned above. The general idea is to modify the aerodrome so it could be used for the IFR traffic. That means to construct the Simple approach lightning system or even the Precision approach category I lightning system. Unfortunately such system including the ILS (Localizer, Glide Path)/DME for Runway 27 will cost an enormous sum of money and it is unlikely to be supported by the investor. However, it is needed to add that there exist cheaper precision approaches that should be evaluated too, for example GNSS based approaches. However, Appendix N of the L11 clearly states that the uncontrolled aerodromes may use non-precision approaches only. It is important to introduce a type of approach which will reduce the requirements for the ground equipment to minimum. Therefore it is recommended to introduce the RNP APCH down to LPV minima, because this type of approach nearly equals the ILS CAT I. as far as the precision is concerned. Substantial problems could occur in the surrounding airspace. Contemporary ATZ essentially borders with temporary reserved area LK TRA 79 that could be activated between FL 75 and FL 245. When activated, the approach to RWY 27 may be problematic. On the grounds of this issue, supplementary consultations with the Armed Forces of the Czech Republic will have to be held.

\section{B. Hradec Králové}

Another highly important aerodrome suitable for the TIZ is Airport Hradec Králové. It possesses a 2400 m long concrete runway with four connected taxiways. APRON is certified for six GA aircrafts of the category A, one aircraft of the category $\mathrm{C}$ and two aircrafts of the category $\mathrm{B}$. The runway contains runway designation marking, centre line, threshold marking, aiming point marking and also touchdown zone marking. Significantly, the aerodrome has Simple approach lighting system, runway edge lights, runway threshold lights, runway end lights, taxiway and APRON edge lights and aeronautical beacon. Notably, whole airport is enclosed with a fence which is important for both safety and security of the airport. Hradec Králové is one of the most progressive uncontrolled aerodrome of all since it considers GNSS approach for IFR traffic and it uses a passive surveillance system ERA in a pilot scheme. According to the aerodrome statistics the number of movements has been increasing every year and international flights are not negligible number of them. Hradec Králové has a large advantage over other aerodromes which is routes for combined IFR/VFR flights on which pilots are allowed to descent to MRVA and then are obliged to cancel their flight plans. Restricted areas around does not pose a threat to air traffic, yet coordination with Armed Forces is recommended.

\section{Moravská Třebová}

Third selected aerodrome that is suitable for the TIZ is Moravská Třebová. On the contrary of the fact that it does not have highly equipped infrastructure, it is still appropriate for the TIZ implementation. That is because of the reason it contains certain potential. The aerodrome has $714 \mathrm{~m}$ long bitumen runway which was built in 2013. It contains the runway designation marking, centre line, threshold marking and runway edge marking. Moreover, this aerodrome uses a NDB beacon, unfortunately it will be cancelled in 2018 as it is mentioned in the AIC A 1/2012. The most important fact about Moravská Třebová is that there exists a determination to develop the aerodrome. The recently built runway could be an impulse for the aerodrome and it could be outset of a further development.

\section{Plzeñ - Líně}

Final very significant aerodrome with a promising future is Airport Plzeň - Líně. It possesses a $1450 \mathrm{~m}$ long concrete runway with two connected taxiways. There used to be two more taxiways, unfortunately the condition of their surface is unsatisfactory and therefore it is forbidden to use them. On the other hand it is a good start and taxiways can be reconstructed. The runway contains runway designation marking, centre line, threshold marking and runway edge marking. As far as the technical equipment is concerned, the aerodrome does not possess very abundant equipment, however, there are intensions to modernize the aerodrome in the near future. Aerial photographs of the aerodromes indicate that there was approach lighting system in the past, from which at least bedrock could be used for the future approach lighting system construction. Furthermore, the potential of the airport will be most likely developed in the future. The zoning plan of the Plzeň region clearly states that a new highway intersection is about to be constructed near the airport and the aerodrome's runway length and protected zones will be extended. Moreover, it is obvious that the owner of the Airport Plzeň - Líně has intentions to develop the airport radically. According to the Airport Plzeň - Líně website, the aim of the company is to transform the aerodrome into regional international airport for a person transport and a cargo transport with gradually progressive frequency of flights per day. 


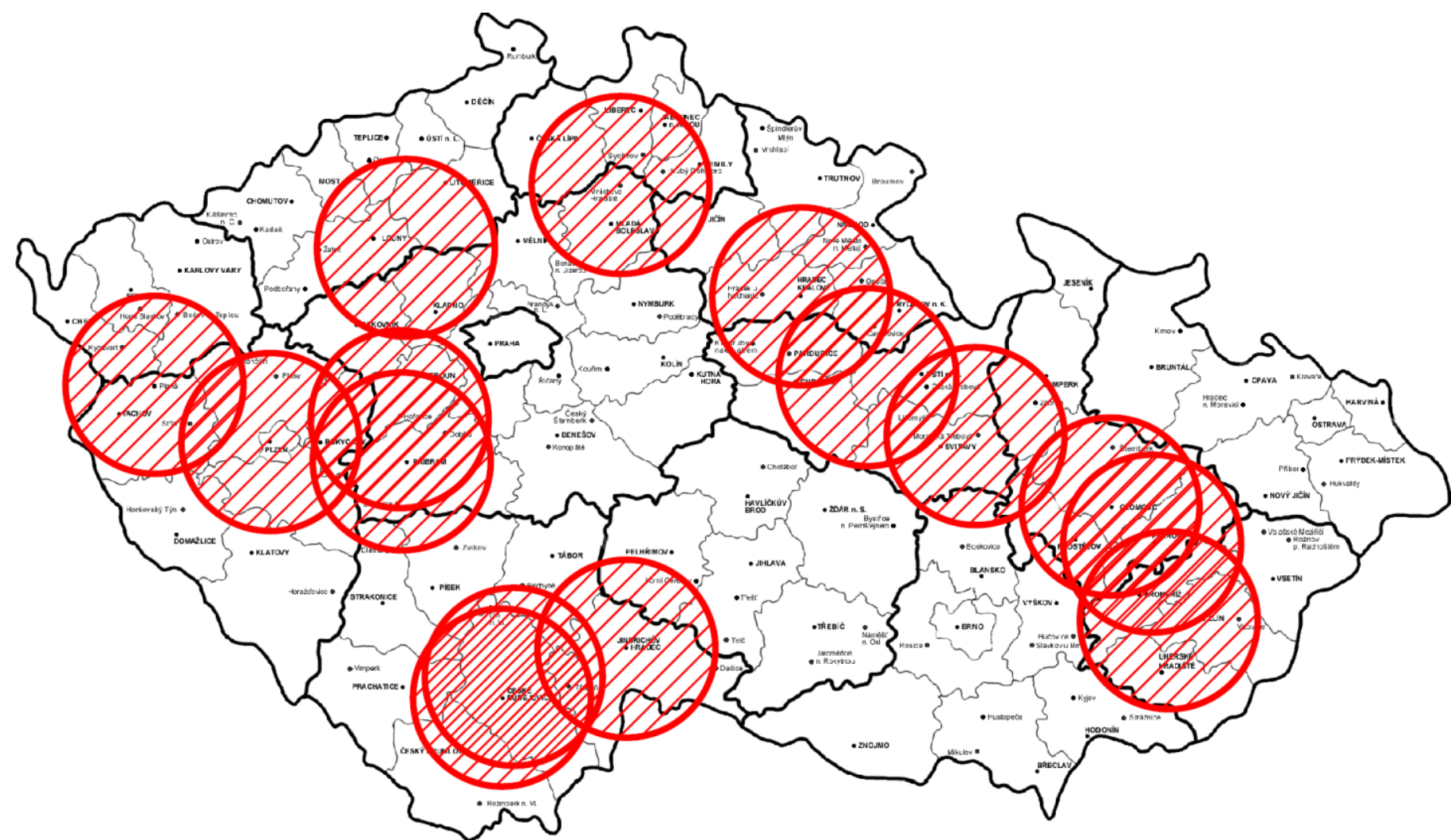

Figure 2. Location of all the pre-selected aerodromes in the $\mathrm{CZ}$

developments afterwards. The optimal suggested procedure is to prepare the needed legislative changes and try to implement them as soon as possible. This act may entice the investors who will be interested in a further aerodrome development. The analysed documents show that the suggested change would definitely help the regional aerodromes and consequently the region itself. It is recommended to implement the Traffic Information Zone on one aerodrome only and observe the situation closely. Provided that the pilot scheme proves to be useful, it can be extended to other selected aerodromes. Such a pilot scheme is suggested to take place on the Airport Hradec Králové and that is because the aerodrome's highly developed status.

\section{F. Needed legislative changes}

The implementation of the TIZ into Czech legislation would not be very problematic and it will mainly affect regulation L11 - Appendix N, Regulation L7030 and AIP where it is needed to modify the part ENR 1.3 and ENR 1.4. Furthermore, in part ENR 1.1. there is needed to include the definition of the TIZ and provided services and define requirements for the mandatory two-way radio communication.

\section{CONCLUSION}

Traffic Information Zone is an instrument that could substantially improve the quality of the air traffic in the Czech Republic. The current status of the Czech airspace shows that it is necessary to improve it constantly. Under the given circumstances it will be needed to distribute the air traffic to the regional aerodromes since the large civil aerodromes will be glutted. According to the current stance of the EU to the regional development, financial resources should be obtained 
from subsidies of the EU and this fact could help the regional aerodromes to develop.

TIZ represents a modern approach to uncontrolled aerodromes and thanks to the experience of some European countries, it can be stated that the contribution of this kind of airspace would be valuable for the Czech aviation.

\section{REFERENCES}

[1] AIP ČR [online].

Available <http://lis.rlp.cz/ais_data/www_main_control/frm_cz_aip.htm>

[2] EUROCONTROL Manual for Aerodrome Flight Information Service (AFIS). In: EUROCONTROL Publications. Brusel, 2010, Edition 1.0. Available at: 〈http://www.skybrary.aero/bookshelf/books/1446.pdf>

[3] L standards - ICAO Annexes [online]. Available at 〈http://lis.rlp.cz/predpisy/predpisy/index.htm>

[4] AIP Norway [online]. Available at <https://www.ippc.no/norway_aip/current/main_no.html>

[5] KRAUS, Jakub, Karel JEŘÁBEK a Tomáś SOPORSKÝ. ANALYSIS OF CZECH AERODROMES IN TERMS OF THE INTRODUCTION OF AN INSTRUMENT APPROACH. In: Konference Increasing Safety and Quality in Civil and Military Air Transport [online]. Žilina: Žilinská univerzita v Žilině, Fakulta prevádzky a ekonomiky dopravy a spojov, 2013 [cit. 2014-03-20]. ISBN 978-80-554-0665-7. Available at:
<http://madgroup.fd.cvut.cz/www/upload/files/Analyza_vyuziti_SBAS_ SGS12_final.pdf >

[6] JIHOČESKÉ LETIŠTĚ ČESKÉ BUDĚJOVICE A.S. Studie využitelnosti letiště České Budějovice. České Budějovice, 2006.

[7] Letiště mezi roky 2013 a 2014. Letiště České Budějovice a.s. [online]. 11.12.2013 [cit. 2014-03-21]. Available at: <http://www.airportcb.cz/cz/news/19/aktuality.html?page=4>

[8] Letištní řád Hradec Králové. FARKAŠ a GRYGA. Letiště Hradec Králové [online]. 2014 [cit. 2014-04-20]. Available at: $<$ http://www.lshk.cz/public/Image/sekce-typ-

123/letistni_rad_2014.pdf>

[9] O letiště České Budějovice je zájem v Rusku. Letiště České Budějovice a.s. [online]. 5.10.2013 [cit. 2014-04-06]. Available at: <http://www.airport-cb.cz/index.php?\&page=6>

[10] Letištní řád Plzeň/Líně. Transpark.eu [online]. 2014 [cit. 2014-05-04] Available at: <http://www.transpark.eu/cs/letiste-plzen/letistni-rad/>

[11] Plane Station Pilsen: ZÚR. Plane Station Plzeň [online]. 2014 [cit. 2014 05-04]. Available at: 〈http://www.transpark.eu/cs/pro-developery/zur/>

[12] Expert consultations. Head of AFIS department, LKCS: Miroslav HOLAK. April 2014.

[13] MOŠNIČKA, Jiří. Možnosti využití různých druhů RNAV približení pro všeobecné letectví v $\check{C} R$. Praha, 2012. Diplomová práce. ČVUT v Praze, Fakulta dopravní.

[14] JIHOČESKÉ LETIŠTĚ ČESKÉ BUDĚJOVICE A.S. Studie využitelnosti letiště České Budějovice. České Budějovice, 2006. 